\title{
Polar Lipid and Isoprenoid Quinone Composition in the Classification of Staphylococcus
}

\author{
By M. R. NAHAIE, ${ }^{1}$ M. GOODFELLOW, ${ }^{*}$ D. E. MINNIKIN ${ }^{2}$ AND \\ V. HÁ JEK ${ }^{3}$ \\ Departments of Microbiology ${ }^{1}$ and Organic Chemistry ${ }^{2}$, The University, Newcastle upon Tyne \\ $N E 17 R U, U K$ \\ ${ }^{3}$ Department of Microbiology, School of Medicine, Palacký University, Olomouc, Czechoslovakia
}

(Received 7 February 1984; revised 19 April 1984)

\begin{abstract}
Representatives of 13 species of Staphylococcus were examined using a small-scale procedure for the sequential extraction of isoprenoid quinones and polar lipids. Menaquinones were the only isoprenoid quinones found in the 77 test strains which were divided into three groups based upon the predominant isoprenologue detected: (i) $S$. hyicus subsp. hyicus, $S$. sciuri subsp. lentus and $S$. sciuri subsp. sciuri contained unsaturated menaquinones with six isoprene units; (ii) $S$. capitis, $S$. cohnii, $S$. epidermidis, $S$. haemolyticus, $S$. hominis, $S$. hyicus subsp. chromogenes, $S$. intermedius, $S$. saprophyticus, $S$. simulans, $S$. warneri and $S$. xylosus contained unsaturated menaquinones with seven isoprene units and (iii) $S$. aureus contained unsaturated menaquinones with eight isoprene units and varying amounts of the corresponding lower isoprenologue. All of the organisms contained very similar polar lipid patterns consisting of diphosphatidylglycerol, phosphatidylglycerol, $\beta$-gentiobiosyl diacylglycerol and a number of glycolipids and phospholipids. One of the glycolipids was chromatographically indistinguishable from $\beta$-gentiotriosyl diacylglycerol. Lysylphosphatidylglycerol was a major component in $S$. aureus and $S$. intermedius but was usually present in minor amounts in the coagulase-negative strains. The polar lipid data underline the homogeneity of the genus Staphylococcus and distinguish staphylococci from aerobic, Gram-positive cocci and from the phylogenetically related aerobic, endospore-forming bacteria. Menaquinone composition can also be used to separate staphylococci from other aerobic, Gram-positive cocci.
\end{abstract}

\section{INTRODUCTION}

Staphylococci form a well-defined taxon (Kloos, 1980; Kloos \& Schleifer, 1981) that is phylogenetically closer to Bacillus than to Micrococcus (Stackebrandt \& Woese, 1979, 1981; Mordarski et al., 1981a). The genus Staphylococcus has been the subject of marked taxonomic revision since the last edition of Bergey's Manual of Determinative Bacteriology (Baird-Parker, 1974) and currently contains 16 species described primarily on the basis of biochemical, chemical, morphological and physiological properties (Skerman et al., 1980; Kilpper-Bälz \& Schleifer, 1981; Schleifer \& Fischer, 1982; Schleifer et al., 1982; Kloos \& Schleifer, 1983). The status of most of the recently described species is supported by DNA-DNA pairing and protein homology data (Meyer \& Schleifer, 1978; Schleifer et al., 1979, 1982; Goodfellow et al., 1980; Kilpper-Bälz \& Schleifer, 1981; Kloos \& Wolfshohl, 1982; Schleifer \& Fischer, 1982; Kloos \& Schleifer, 1983) and simplified schemes have been recommended for the identification of human Staphylococcus species (Kloos \& Schleifer, 1975; Kloos \& Wolfshohl, 1982). A number of workers have questioned the integrity of both recently described and well-established staphylococcal species (Feltham, 1979; Hájek \& Schindler, 1981; Mordarski et al., 1981 b), others the 
reliability of tests currently employed for the identification of unknown strains (Heddaeus et al., 1978, 1981; Marples, 1981; Feltham \& Sneath, 1982) and there is evidence that additional centres of variation exist within the genus (Weckbach \& Langlois, 1976; Feltham, 1979; Kloos \& Wolfshohl, 1982; Goodfellow et al., 1983; Schumacher-Perdreau et al., 1983).

Lipid markers are being increasingly used for both the classification and identification of Gram-positive bacteria (see Lechevalier, 1977; Minnikin et al., 1978; Minnikin \& Goodfellow, $1980,1981)$; especially valuable data have been derived from the analysis of fatty acids (Bousfield et al., 1983; Collins et al., 1982a), isoprenoid quinones (see Collins \& Jones, 1981) and polar lipids (Lechevalier et al., 1977; Minnikin et al., 1978; Collins et al., 1982 b). Staphylococci contain qualitatively similar fatty acid profiles consisting of major amounts of iso- and anteisomethyl branched components (Durham \& Kloos, 1978; Sincoweay et al., 1981) and have unsaturated menaquinones (MK) as their sole respiratory isoprenoid quinone (see Collins \& Jones, 1981). Staphylococcus aureus strains contain menaquinones with eight isoprene units, abbreviated as MK-8, as their main component, although MK-7 is also present in substantial proportions (Cawthorne et al., 1967; Frerman \& White, 1967; Jeffries et al., 1967a,b, 1969; Hammond \& White, 1969; Jeffries, 1969; Yamada et al., 1976; Collins, 1981). Little is known about the distribution of menaquinones amongst coagulase-negative staphylococci, though there is evidence of two distinct menaquinone patterns each of which can be distinguished readily from the profile characteristic for $S$. aureus (Bishop et al., 1962; Jeffries et al., 1967 , 1969; Jeffries, 1969; Kushwaha \& Kates, 1976; Yamada et al., 1976; Collins et al., 1980; Collins, 1981).

Polar lipid analyses have been restricted to $S$. aureus (Macfarlane, 1962; Houtsmuller \& van Deenen, 1965; White \& Frerman, 1967; Brundish \& Baddiley, 1968; Gould \& Lennarz, 1970; Joyce et al., 1970; Short \& White, 1970; Rédai et al., 1971; Komura et al., 1975) and $S$. epidermidis strains (Komaratat \& Kates, 1975; Komura et al., 1975) and in most of these investigations the emphasis has been either on the effect of growth conditions on polar lipid composition or on the characterization of specific phospholipid fractions. Staphylococcus aureus and $S$. epidermidis contain major amounts of diphosphatidylglycerol and phosphatidylglycerol but the former also possesses lysylphosphatidylglycerol, diglucosyldiacylglycerol and occasionally a glycophospholipid and the latter phosphatidic acid, phosphatidyl diglycosyldiglyceride and unknown phospholipids.

In the present study, representatives of 13 species of Staphylococcus were examined to determine the value of menaquinones and polar lipids in their classification.

\section{METHODS}

Cultures. The test strains (Table 1) were maintained on nutrient agar (Oxoid) supplemented with glucose ( $2 \%$, $\mathrm{w} / \mathrm{v}$ ), and as frozen glycerol suspensions at $-25^{\circ} \mathrm{C}$ (Wellington \& Williams, 1979). More detailed information on the strain histories can be found elsewhere (Goodfellow et al., 1983).

Cultivation. Staphylococcus aureus $\mathrm{SCH} 103$, the $S$. hyicus and coagulase-negative strains were grown overnight at $35^{\circ} \mathrm{C}$ in $2 \mathrm{ml}$ Trypticase Soy Broth supplemented with glucose $(0.25 \%$, w/v, TSB; Difco). Samples $(0.05 \mathrm{ml})$ of these cultures were used to seed $50 \mathrm{ml} \mathrm{TSB}$ in flasks which were shaken on a rotary shaker at 200 r.p.m., $35^{\circ} \mathrm{C}$. The $O D$ of cultures was checked after $6 \mathrm{~h}$ using two different wavelengths, and when $\mathrm{OD}_{600}$ reached $2 \cdot 5$ or $\mathrm{OD}_{450}$ reached $3.5,6 \mathrm{ml}$ of each culture was transferred to 1 litre conical flasks containing $300 \mathrm{ml}$ TSB to give approximately $10^{8}$ c.f.u. per $50 \mathrm{ml}$. Inoculated flasks were shaken in an orbital incubator (150 r.p.m.) at $35^{\circ} \mathrm{C}$ for $24 \mathrm{~h}$. The cultures were then checked for purity, killed by the addition of $1 \mathrm{ml}$ formalin $(40 \%, v / v)$, harvested by centrifugation at $3000 \mathrm{~g}$ for $20 \mathrm{~min}$, washed twice with $67 \mathrm{~mm}$-Sorenson phosphate buffer at pH 7.0 and freezedried. The remaining $S$. aureus strains and all of the $S$. intermedius strains were grown on sheep blood agar $(5 \%$, $\mathrm{v} / \mathrm{v}$ ) at $37^{\circ} \mathrm{C}$ for $24 \mathrm{~h}$ and kept for $2 \mathrm{~d}$ at ambient temperature in daylight; harvested biomass was washed twice with normal saline and freeze-dried.

Extraction of isoprenoid quinones and polar lipids. Isoprenoid quinones and polar lipids were extracted using a recently developed procedure (Minnikin et al., 1984). Equal volumes ( $2 \mathrm{ml}$ ) of aqueous methanolic $\mathrm{NaCl}(10 \mathrm{ml}$ $0.3 \%, w / v$, aqueous $\mathrm{NaCl}$ added to $100 \mathrm{ml}$ methanol) and petroleum ether (b.p. $60-80^{\circ} \mathrm{C}$ ) were added to $100 \mathrm{mg}$ biomass in polytetrafluoroethylene-lined capped tubes and the contents mixed on a tube rotator for $15 \mathrm{~min}$. The tubes were then centrifuged at low speed for $5 \mathrm{~min}$, the upper layer removed and the extraction repeated with $1 \mathrm{ml}$ petroleum ether. The combined extracts were evaporated under nitrogen at about $37^{\circ} \mathrm{C}$ to provide crude isoprenoid quinones. The residual aqueous layers remaining after isoprenoid quinone extraction were treated 
Table 1. Designation and source of test strains

Laboratory number

SCH103*

SCH113-SCH115

SCH116-SCH118

SCH119-SCH121

SCH122-SCH124

SCH125-SCH 127

SCH128-SCH130

SCH104*

SCH92, SCH93

$\mathrm{SCH} 105^{*}$

SCH25, SCH30, SCH32, SCH 37

SCH106*

$\mathrm{SCH} 107^{*}$

SCH108*

SCH98, SCH99

$\mathrm{SCH} 167^{*}, \mathrm{SCH} 164$

$\mathrm{SCH} 170$

SCH157*

SCH154, SCH161

SCH131-SCH133

SCH134-SCH136

SCH137-SCH139

SCH140*-SCH142

SCH94*, SCH95

SCH89*

SCH90

SCH91*

SCH110*

SCH4, SCH6, SCH9, SCH96,

SCH97, SCH221

$\mathrm{SCH} 111^{*}$

SCH102

$\mathrm{SCH} 12^{*}$

$\mathrm{SCH} 12, \mathrm{SCH} 16, \mathrm{SCH} 31$

SCH1, SCH41, SCH46

SCH5, SCH38, SCH43
Strain designation/Source $\dagger$

Staphylococcus aureus NCTC 8532; isolated from human pleural fluid

$S$. aureus biotype A; V. Hájek, Microbiological Institute, Palacky University, Olomouc, Czechoslovakia, B13, B31, B42; patients with bronchopneumonia complicating influenza infection

$S$. aureus biotype B; V. Hájek, V1, V5, V15; slaughtered pigs

$S$. aureus biotype B; V. Hájek, S26, S41, S49; chickens with septicaemia

$S$. aureus biotype C; V. Hájek, M1, M39, M85; cows with mastitis

S. aureus biotype C; V. Hájek, R18, R28, R31; sheep

$S$. aureus biotype D; V. Hájek, Z10 (CCM5771), Z17, Z20; hares

Staphylococcus capitis; NCTC 11045

S. capitis; G. Pulverer, Institute of Hygiene, University of Cologne, Cologne, FRG, 152, 203

Staphylococcus cohnii NCTC 11041; isolated from human skin

S. cohnii; G. Pulverer, 182, 202, 216, 251; cow's milk

Staphylococcus epidermidis NCTC 11047

Staphylococcus haemolyticus NCTC 11042

Staphylococcus hominis NCTC 11320

$S$. hominis; G. Pulverer, 263, 100

Staphylococcus hyicus subsp. chromogenes; S. Rowinski, Polish Collection of Microorganisms, Institute of Immunology and Experimental Therapy, Wroclaw, Poland, SH220 (NCTC 10530), SH208; pigs

$S$. hyicus subsp. chromogenes; S. Rowinski, SH226; cow, Belgium

Staphylococcus hyicus subsp. hyicus; S. Rowinski, SH30 (NCTC 10350); isolated from swine

S. hyicus subsp. hyicus; S. Rowinski, SH59, SH170; isolated from swine, Belgium and England, respectively

Staphylococcus intermedius biotype E; V. Hájek, P13 (CCM 5738), P15, P71; dogs

$S$. intermedius biotype E; V. Hájek, K2, K20, K35; horses

$S$. intermedius biotype E; V. Hájek, L91, L103, L105; minks

S. intermedius biotype F; V. Hájek, H11 (NCTC 11048), H12, H17; pigeons

Staphylococcus saprophyticus; G. Pulverer, 075, 247

Staphylococcus sciuri subsp. lentus DSM 20352; isolated from udder of goat S. sciuri subsp. lentus CCM 3472

Staphylococcus sciuri subsp. sciuri DSM 20345; isolated from skin of eastern gray squirrel

Staphylococcus simulans NCTC 11046

S. simulans; G. Pulverer, 28, 37, 70, 119, 166, 41

Staphylococcus warneri; NCTC 11044

$S$. warneri; G. Pulverer, 101

Staphylococcus xylosus NCTC 11043; isolated from human skin

S. xylosus; G. Pulverer, 83, 103, 212

Staphylococcus sp.; G. Pulverer, 16, 298, 349, cluster 11A

Staphylococcus sp.; G. Pulverer, 35, 261, 326, cluster 11B

* Type strain.

† CCM, Czechoslovak Collection of Micro-organisms, Brno, Czechoslovakia; DSM, Deutsche Sammlung von Mikroorganismen, Teilsammlung Darmstadt, 61 Darmstadt, FRG; NCTC, National Collection of Type Cultures, London, UK.

¥ Goodfellow et al. (1983).

using a modification (Card, 1973; Minnikin et al., 1979, 1984) of the method of Bligh \& Dyer (1959) to give a polar lipid extract which was stored at $-20^{\circ} \mathrm{C}$.

Analysis of isoprenoid quinones. Crude isoprenoid quinone samples were dissolved in petroleum ether, applied as $0.5 \mathrm{~cm}$ bands to $10 \times 10 \mathrm{~cm}$ pieces of plastic-backed silica gel sheets (Merck 5735), and developed with petroleum ether/acetone $(96: 4, v / v)$ in the first direction and petroleum ether/toluene $(50: 50, v / v)$ in the second direction. Separated menaquinones were detected with short-wave UV light $(254 \mathrm{~nm})$ and menaquinone bands cut out and extracted by shaking with diethyl ether $(1 \mathrm{ml})$ for $15 \mathrm{~min}$. The extraction was repeated with a further $1 \mathrm{ml}$ diethyl ether, the combined extracts passed through a Pasteur pipette plugged with cotton wool prewashed with diethyl ether, the filtrate evaporated to dryness using nitrogen (around $37^{\circ} \mathrm{C}$ ) and stored in the dark at $-20^{\circ} \mathrm{C}$. Purified 
menaquinones were analysed by mass spectroscopy on an AEI MS9 instrument using a direct insertion probe, an ionizing voltage of $70 \mathrm{eV}$ and a temperature range of $170-220^{\circ} \mathrm{C}$, and by reverse-phase TLC (Collins et al., 1980).

Analysis of polar lipids. Patterns of polar lipids were obtained by spotting samples onto $6.6 \times 6.6 \mathrm{~cm}$ pieces of aluminium-backed silica gel sheets (Merck 5554) and developing with chloroform/methanol/water $(65: 25: 4$, by vol.) in the first direction and chloroform/acetic acid/methanol/water (80:15:12:4, by vol.) in the second direction. All lipids were detected by spraying with $5 \%$ ethanolic molybdophosphoric acid followed by charring at $180^{\circ} \mathrm{C}$. Additional preparations were examined using specific spray reagents for amino groups $(0 \cdot 2 \%$ ninhydrin in water-saturated butanol) (Consden \& Gordon, 1948), $\alpha$-glycols (periodate-Schiff) (Shaw, 1968), lipid phosphate (Dittmer \& Lester, 1964) and sugars ( $\alpha$-naphthol) (Jacin \& Mishkin, 1965).

\section{RESULTS}

Compounds that co-chromatographed with vitamin $\mathrm{K}_{1}$ were the only isoprenoid quinones detected by TLC in extracts of the 74 strains. Purification of the menaquinones, using a twodimensional TLC system, was necessary to avoid spurious peaks in mass spectrometry. The most intense peaks in the mass spectra of the purified menaquinones occurred at $\mathrm{m} / \mathrm{e} 187$ and 225 and were derived from the naphthoquinone nucleus (Azerad \& Cyrot-Pelletier, 1973). All of the mass spectra in the high mass region contained strong peaks corresponding to molecular ions $\left(\mathbf{M}^{+}\right)$and in some cases smaller peaks at $\mathbf{M}^{+}-15$ corresponded to the loss of a methyl group from the molecular ion. The results of the mass spectral analyses of the menaquinones shown in Tables 2 and 3, were confirmed by reverse phase TLC.

The strains of $S$. intermedius contained unsaturated menaquinones with seven isoprene units as the only component; in contrast the $S$. aureus strains possessed major amounts of unsaturated menaquinones with eight isoprene units and varying amounts of MK-7 (Table 2). Some of the $S$. aureus strains contained approximately equal amounts of MK-7 and MK-8 but only the type

Table 2. Peaks corresponding to molecular ions in the mass spectra of menaquinones isolated from representatives of Staphylococcus aureus (biotypes $A-D$ ) and Staphylococcus intermedius (biotypes $E$ and $F$ )

The main component of each series is denoted by +++ , any component greater than $50 \%$ of the main peak by ++ , and all other significant components by + .

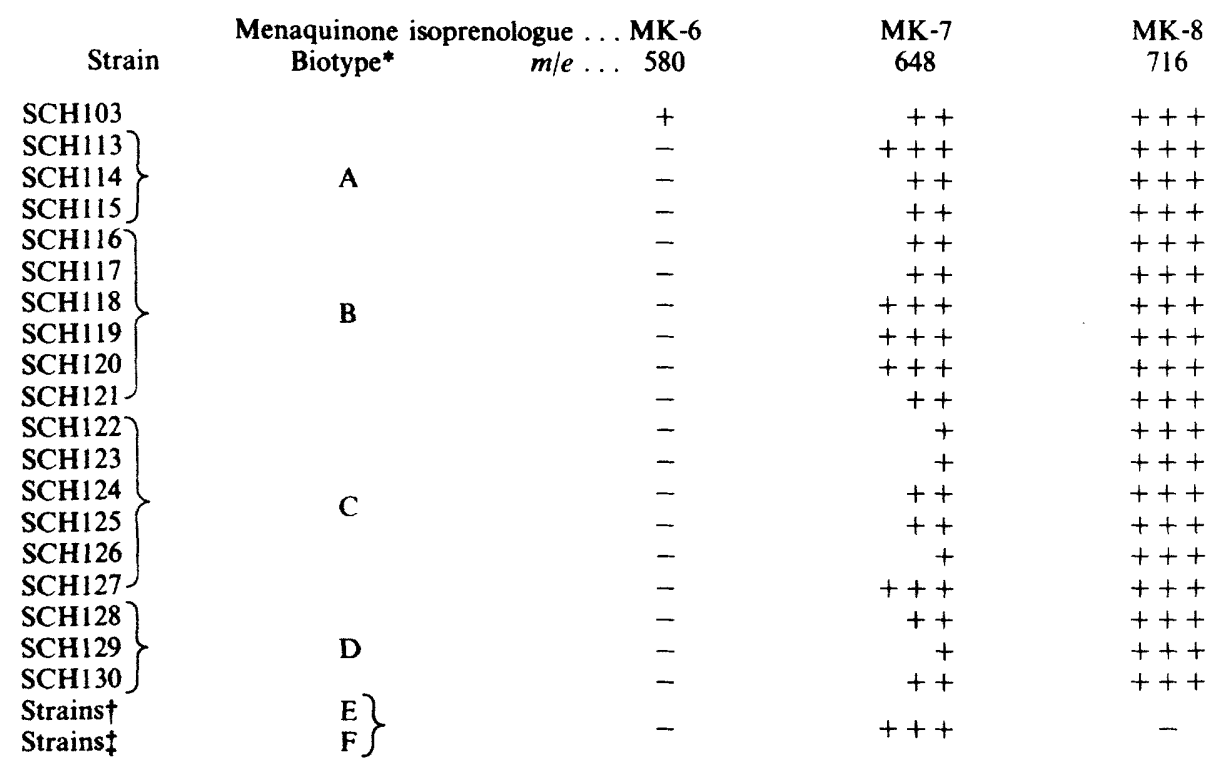

* Biotypes recognised by Hájek \& Marsalek (1971, 1976).

† Strains SCH131, SCH132, SCH133, SCH134, SCH135, SCH136, SCH137, SCH138, SCH1 39 and SCH139 (duplicate).

$\ddagger$ Strains SCH140, SCH140 (duplicate), SCH141 and SCH142. 
Table 3. Peaks corresponding to molecular ions in the mass spectra of menaquinones isolated from representative strains of coagulase-negative Staphylococcus species

The main component of each series is denoted by +++ , any component greater than $50 \%$ of the main peak by ++ , and all other significant components by + .

\begin{tabular}{|c|c|c|c|c|}
\hline Strain & $\begin{array}{r}\text { Menaquinone } \\
\text { isoprenologue } \\
m / e\end{array}$ & $\begin{array}{l}\ldots \mathrm{MK}-6 \\
\ldots 580\end{array}$ & $\begin{array}{c}\text { MK-7 } \\
648\end{array}$ & $\begin{array}{c}\text { MK-8 } \\
716\end{array}$ \\
\hline Staphylococcus capitis & $\begin{array}{l}\text { SCH92 } \\
\text { SCH93 } \\
\text { SCH104 }\end{array}$ & $\begin{array}{l}- \\
- \\
-\end{array}$ & $\begin{array}{l}+++ \\
+++ \\
+++\end{array}$ & $\begin{array}{l}- \\
-\end{array}$ \\
\hline Staphylococcus cohnii & $\begin{array}{l}\text { SCH25 } \\
\text { SCH30 } \\
\text { SCH32 } \\
\text { SCH37 } \\
\text { SCH105 }\end{array}$ & $\begin{array}{l}- \\
- \\
- \\
-\end{array}$ & $\begin{array}{l}+++ \\
+++ \\
+++ \\
+++ \\
+++\end{array}$ & $\begin{array}{l}- \\
- \\
- \\
-\end{array}$ \\
\hline Staphylococcus epidermidis & SCH106 & + & +++ & + \\
\hline Staphylococcus haemolyticus & SCH107 & - & +++ & - \\
\hline Staphylococcus hominis & $\begin{array}{l}\text { SCH98 } \\
\text { SCH99 } \\
\text { SCH108 }\end{array}$ & $\begin{array}{l}- \\
- \\
-\end{array}$ & $\begin{array}{l}+++ \\
+++ \\
+++\end{array}$ & $\begin{array}{l}- \\
+ \\
+\end{array}$ \\
\hline $\begin{array}{l}\text { Staphylocuccus hyicus } \\
\text { subsp. chromogenes }\end{array}$ & $\begin{array}{l}\text { SCH164 } \\
\text { SCH167 } \\
\text { SCH170 }\end{array}$ & $\begin{array}{l}+ \\
+ \\
+\end{array}$ & $\begin{array}{l}+++ \\
+++ \\
+++\end{array}$ & $\begin{array}{l}+ \\
- \\
+\end{array}$ \\
\hline $\begin{array}{l}\text { Staphylococcus hyicus } \\
\text { subsp. hyicus }\end{array}$ & $\begin{array}{l}\text { SCH154 } \\
\text { SCH157 } \\
\text { SCH161 }\end{array}$ & $\begin{array}{l}+++ \\
+++ \\
+++\end{array}$ & $\begin{array}{l}+ \\
+ \\
+\end{array}$ & $\begin{array}{l}- \\
- \\
-\end{array}$ \\
\hline Staphylococcus saprophyticus & $\begin{array}{l}\text { SCH94 } \\
\text { SCH95 }\end{array}$ & - & $\begin{array}{l}+++ \\
+++\end{array}$ & - \\
\hline $\begin{array}{l}\text { Staphylococcus sciuri } \\
\text { subsp. lentus }\end{array}$ & $\begin{array}{r}\text { SCH89 } \\
\text { - SCH89 } \\
\text { SCH90 }\end{array}$ & $\begin{array}{l}+++ \\
+++ \\
+++\end{array}$ & $\begin{array}{l}- \\
- \\
-\end{array}$ & $\begin{array}{l}- \\
- \\
-\end{array}$ \\
\hline $\begin{array}{l}\text { Staphylococcus sciuri } \\
\text { subsp. sciuri }\end{array}$ & $\begin{array}{r}\text { SCH91 } \\
{ }^{*} \mathrm{SCH} 91\end{array}$ & $\begin{array}{l}+++ \\
+++\end{array}$ & - & - \\
\hline Staphylococcus simulans & $\begin{array}{l}\text { SCH4 } \\
\text { SCH6 } \\
\text { SCH9 } \\
\text { SCH96 } \\
\text { SCH110 } \\
\text { SCH221 }\end{array}$ & $\begin{array}{l}+ \\
+ \\
+ \\
+ \\
+ \\
+\end{array}$ & $\begin{array}{l}+++ \\
+++ \\
+++ \\
+++ \\
+++ \\
+++\end{array}$ & $\begin{array}{l}- \\
- \\
- \\
- \\
-\end{array}$ \\
\hline Staphylococcus warneri & $\begin{array}{l}\text { SCH102 } \\
\text { SCH111 }\end{array}$ & - & $\begin{array}{l}+++ \\
+++\end{array}$ & - \\
\hline Staphylococcus xylosus & $\begin{array}{l}\text { SCH12 } \\
\text { SCH16 } \\
\text { SCH31 } \\
\text { SCH112 }\end{array}$ & $\begin{array}{l}- \\
- \\
-\end{array}$ & $\begin{array}{l}+++ \\
+++ \\
+++ \\
+++\end{array}$ & $\begin{array}{l}- \\
+ \\
- \\
-\end{array}$ \\
\hline Staphylococcus sp. & $\begin{array}{l}\text { SCH1 } \\
\text { SCH5 } \\
\text { SCH38 } \\
\text { SCH41 } \\
\text { SCH43 } \\
\text { SCH46 }\end{array}$ & $\begin{array}{l}- \\
- \\
- \\
- \\
+\end{array}$ & $\begin{array}{l}+++ \\
+++ \\
+++ \\
+++ \\
+++ \\
+++\end{array}$ & $\begin{array}{l}+ \\
+ \\
+ \\
+ \\
+ \\
+\end{array}$ \\
\hline
\end{tabular}

- Duplicate cultures.

strain had MK-6 as a minor component. Analyses by reverse phase TLC correlated with these mass spectral data. The remaining staphylococci fell into two broad groups on the basis of menaquinone composition. Thus, $S$. sciuri and $S$. hyicus subsp. hyicus had major amounts of MK-6, and in the second group MK-7 was the major isoprenologue. It was also possible to distinguish between $S$. sciuri and $S$. hyicus subsp. hyicus as only the latter had minor amounts of MK-7. Similarly, all of the representatives of $S$. capitis, $S$. cohnii, $S$. haemolyticus, $S$. saprophyticus and $S$. 
warneri, and all but one of the $S$. xylosus strains contained MK-7 as the only component whereas $S$. hominis and strains received as Staphylococcus sp. also had minor amounts of MK-8. Further, all but one of the $S$. simulans strains possessed small amounts of MK-6, whereas $S$. epidermidis SCH106 and two of the three strains of $S$. hyicus subsp. chromogenes contain minor amounts of both MK-6 and MK-8.

The results of the two-dimensional TLC analyses of the polar lipids of representative staphylococci are shown in Fig. 1; all 74 strains gave similar polar lipid patterns. The major

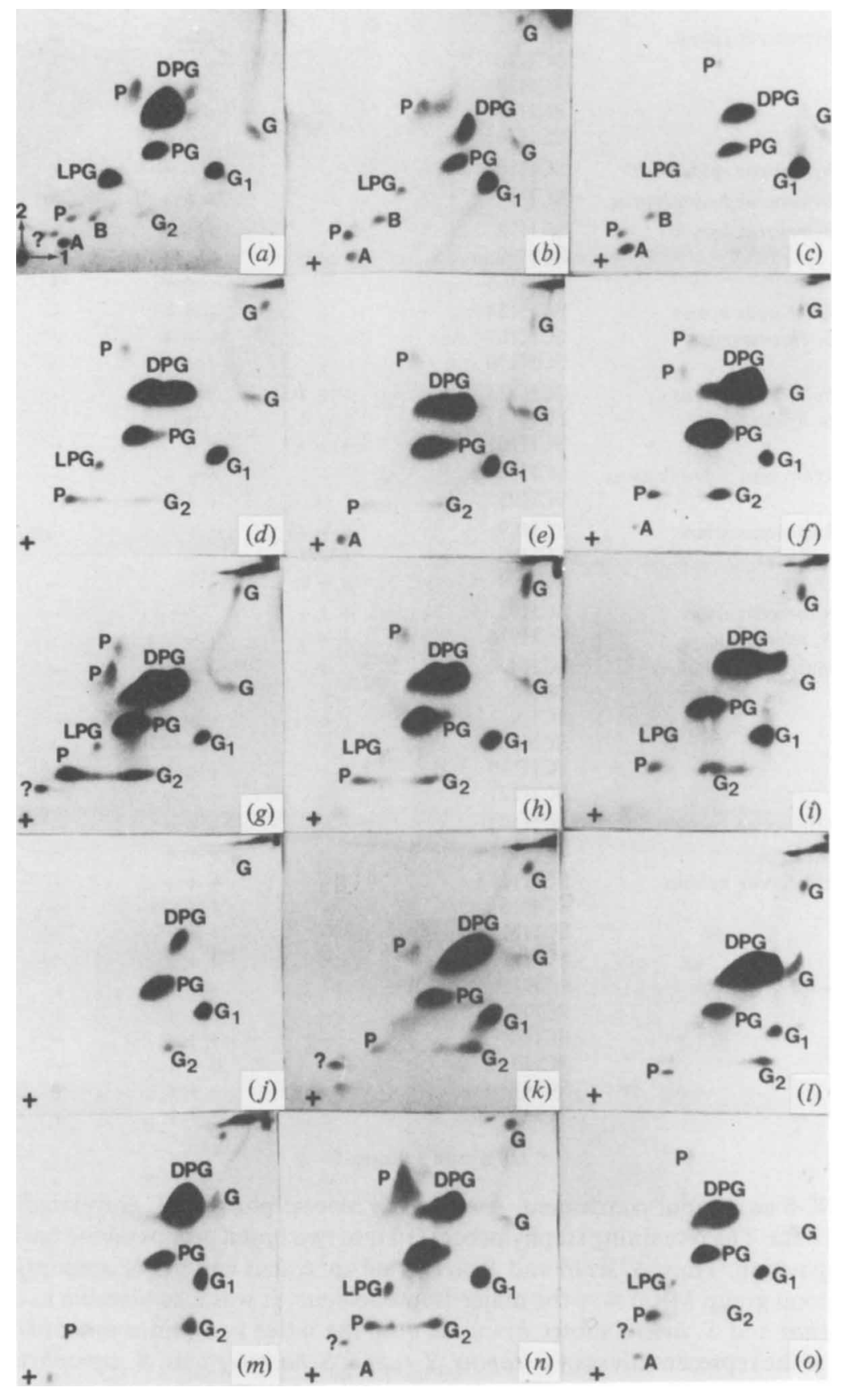


components co-chromatographed with and had the staining properties of diphosphatidylglycerol (DPG), phosphatidylglycerol (PG) and $\beta$-gentiobiosyl diacylglycerol $\left(G_{1}\right)$. Lysylphosphatidylglycerol (LPG) was a major component in all of the coagulase-positive strains and was also present in the coagulase-negative strains but usually in minor amounts. The strains also contained a number of unknown phospholipids (P) and glycolipids (G) (Fig. 1). The polar glycolipid $\left(G_{2}\right)$ (Fig. 1) corresponded in chromatographic behaviour to a $\beta$-gentiotriosyl diacylglycerol from the lipids of Bacillus species, previously observed as an unidentified trace component in the lipids of $S$. aureus DSM 346 (Fischer et al., 1978).

\section{DISCUSSION}

It is evident from the present study that qualitative polar lipid analyses are of little value in the subgeneric classification of Staphylococcus as all of the $S$. aureus, $S$. capitis, S. cohnii, $S$. epidermidis, $S$. haemolyticus, $S$. hominis, $S$. hyicus, $S$. intermedius, $S$. saprophyticus, $S$. sciuri, $S$. simulans, $S$. warneri and $S$. xylosus strains contained DPG, PG, LPG, a glycolipid chromatographically indistinguishable from the $\beta$-gentiobiosyl diacylglycerol of $S$. aureus (Shaw, 1975; Fischer $e$ al., 1978) and several unknown glyco- and phospholipids. An essentially similar polar lipid pattern has been reported for $S$. (Micrococcus) caseolyticus (Whiteside et al., 1971). In contrast to nearly all of the $S$. aureus and $S$. intermedius strains, most of the coagulase-negative cultures contained only traces of LPG, indeed, the lipid could not always be detected on the chromatograms. Staphylococcus aureus SCH103 grown on TSB, gave the same polar lipid pattern as the $S$. aureus strains grown on sheep blood agar.

The polar lipid patterns of staphylococci distinguish them from other aerobic, Gram-positive cocci, and from aerobic, endospore-forming bacteria. Thus, Bacillus, Planococcus and Sporosarcina strains typically contain phosphatidylethanolamine as well as phosphatidylglycerol, and diphosphatidylglycerol (Komura et al., 1975; Minnikin \& Goodfellow, 1981), and Micrococcus luteus has phosphatidylglycerol, phosphatidylinositol and a dimannosyl diacylglycerol (Whiteside et al., 1971; De Siervo \& Salton, 1971; Shaw, 1975). It is interesting that staphylococci and aerobic, endospore-forming bacilli have the same $(1 \rightarrow 6)-\beta$-linked diglucosyl (gentiobiosyl) diacylglycerol given their close phylogenetic relationship (Stackebrandt \& Woese, 1979,1981 ). In contrast, micrococci have a different glycolipid based on mannose but streptococci may also contain a diglycosyl diacylglycerol but with a $(1 \rightarrow 2)-\alpha$-linkage (Shaw, 1975; Lechevalier, 1977).

The menaquinone data extend and confirm earlier investigations notably that of Collins (1981) who assigned a small number of staphylococci to three groups on the basis of whether they contained MK-6, MK-7 or MK-8 as the predominant isoprenologue. In the present study, the $S$. sciuri and $S$. hyicus subsp. hyicus strains contained major amounts of MK-6, the $S$. aureus strains major proportions of MK-8 and S. capitis, S. cohnii, S. epidermidis, S. haemolyticus, S. hominis, $S$. intermedius, S. saprophyticus, S. simulans, S. warneri and $S$. xylosus had MK-7 as the predominant isoprenologue. The presence of unsaturated menaquinones distinguishes staphylococci from $M$. luteus and related strains which contain dihydrogenated menaquinones with

Fig. 1. Two-dimensional TLC of the polar lipids of the type strains of $(a) S$. aureus SCH103, (b) $S$. capitis SCH104, (c) S. cohnii SCH25, (d) S. epidermidis SCH106, (e) S. haemolyticus SCH107, ( $f$ ) $S$. hominis SCH108, (g) S. hyicus subsp. chromogenes SCH167, (h) $S$. hyicus subsp. hyicus SCH157, (i) $S$. intermedius SCH140, $(j) S$. saprophyticus SCH94, $(k) S$. sciuri subsp. lentus SCH89, $(l) S$. sciuri subsp. sciuri SCH91, (m) S. simulans SCH110, (n) $S$. warneri SCH111 and (o) $S$. xylosus SCH112. Chloroform/methanol/water $(65: 25: 4$, by vol.) was used in the first direction followed by chloroform/acetic acid/methanol/water (85:15:12:4, by vol.) in the second direction. Abbreviations: DPG, diphosphatidylglycerol; PG, phosphatidylglycerol; LPG, lysylphosphatidylglycerol; $\mathbf{G}_{1}$, gentiobiosyl diacylglycerol; $G_{2}$, possible gentiotriosyl diacylglycerol; $G$, unknown glycolipid; P, unknown phospholipid; A, positive to ninhydrin; B, positive to periodate-Schiff.

Photocopies of the polar lipid patterns of the remaining strains have been deposited with the British Lending Library, Boston Spa LS23 7BQ, UK as Supplementary Publication no. 28017. Copies may be obtained from the BLL on demand. Where possible, requests should be accompanied by prepaid coupons (held by many university and technical libraries and by the British Council). 
seven, eight or nine isoprene units (Jeffries et al., 1967 b, 1969; Jeffries, 1969; Yamada et al., 1976). Similarly, staphylococci can be separated from those streptococci that contain major amounts of MK-9 or demethyl-menaquinones with nine isoprene units and from Aerococcus, Gemella, Leuconostoc, Pediococcus and most Streptococcus strains which lack isoprenoid quinones (Collins \& Jones, 1981). They cannot, however, be distinguished from Bacillus, Sporolactobacillus and Sporosarcina strains which have MK-7 as the major isoprenologue (Minnikin \& Goodfellow, 1981) nor from Streptococcus faecium strains containing major amounts of MK-8 (Collins \& Jones, 1981).

The detection of major amounts of MK-8 and substantial proportions of MK-7 in $S$. aureus strains is in agreement with previous studies (Cawthorne et al., 1967; Jeffries et al., 1967 b, 1969; Jeffries, 1969; Yamada et al., 1976; Collins, 1981); some of these workers reported the presence of minor amounts of MK-6, others MK-9. It is known that the relative amounts of such isoprenologues vary between strains (Jeffries et al., 1969). It is possible that the presence or absence of such components is influenced by the growth regime, since in the present study MK-9 was not detected, but traces of MK-6 were found in the $S$. aureus strain grown on TSB. The presence of only major amounts of MK-7 in the $S$. intermedius strains distinguishes them from $S$. aureus and provides further support for assigning coagulase-positive staphylococci to two species. Thus, representatives of $S$. aureus and $S$. intermedius have few DNA sequences in common (Meyer \& Schleifer, 1978), can be separated readily from one another and from $S$. hyicus in numerical phenetic surveys (Hájek \& Schindler, 1981; Goodfellow et al., 1983), show differences in wall composition (Schleifer \& Kandler, 1972; Hájek, 1976; Schleifer et al., 1976), in the configuration of lactic acid produced from glucose under anaerobic conditions, in esterase pattern and in the occurrence of fructose-1,6-diphosphate-activated L-lactate dehydrogenase (Schleifer et al., 1976). The inability of Feltham (1979) to separate $S$. intermedius and S. hyicus strains can probably be attributed to an overreliance placed on biochemical properties in his numerical phenetic study.

The assignment of coagulase-negative staphylococci to two broad groups on the basis of menaquinone composition is in agreement with earlier preliminary studies (Jeffries et al., 1967 b, 1969; Jeffries, 1969; Kushwaha \& Kates, 1976; Yamada et al., 1976; Collins et al., 1980; Collins, 1981). It is especially interesting that the two subspecies of $S$. sciuri are characterized by unsaturated menaquinones with six isoprene units, and that menaquinone data provide some support for the continued recognition of the two subspecies of $S$. hyicus (Devriese et al., 1978). However, further studies on additional strains are needed to determine whether menaquinone analysis can be used to distinguish between the two subspecies of $S$. hyicus; Hájek \& Schindler (1981) considered that the latter merited species status. Additional studies are also needed to see whether coagulase-negative species containing major amounts of MK-7 can be distinguished on the basis of the minor amounts of menaquinones they contain.

The present results are in good agreement with preliminary studies which showed the value of polar lipids and isoprenoid quinones in staphylococcal systematics (Komura et al., 1975; Collins \& Jones, 1981). The polar lipid data help underline the homogeneity of the genus Staphylococcus, but further studies are needed to evaluate the full potential of menaquinone analyses in the identification of staphylococcal species. Both the polar lipid and menaquinone results argue against the suggestion (Feltham, 1979) that $S$. sciuri be moved to a new genus Cellobiosococcus. DNA homology and catalase immunological studies also support the continued recognition of $S$. sciuri (Kloos, 1980).

We are indebted to colleagues who kindly provided cultures (Table 1) and to P. Kelly and S. H. Addison for mass spectroscopy.

\section{REFERENCES}

Azerad, R. \& Cyrot-Pelletier, M. D. (1973). Structure of configuration of the polyisoprenoid side chain of dihydromenaquinones from myco- and corynebacteria. Biochimie 55, 591-603.
BAIRD-PARKer, A. C. (1974). Staphylococcus. In Bergey's Manual of Determinative Bacteriology, 8th edn, pp. 483-489. Edited by R. E. Buchanan \& N. E. Gibbons. Baltimore: Williams \& Wilkins. 
Bishop, D. H. L., PANDYA, K. P. \& King, H. K. (1962). Ubiquinone and vitamin $\mathbf{K}$ in bacteria. Biochemical Journal 83, 606-614.

BLIGH, E. G. \& DYER, W. J. (1959). A rapid method of total lipid extraction and purification. Canadian Journal of Biochemistry and Physiology 37, 911-917.

Bousfield, I. J., SMITH, G. L., DANDO, T. R. \& HobBs, G. (1983). Numerical analysis of total fatty acid profiles in the identification of coryneform, nocardioform and some other bacteria. Journal of General Microbiology 129, 375-394.

BRundish, D. E. \& BADdiley, J. (1968). Synthesis of glucosylglycerols and diglucosylglycerols, and their identification in small amounts. Carbohydrate $R e$ search 8, 308-316.

CARD, G. L. (1973). Metabolism of phosphatidylglycerol, phosphatidylethanolamine and cardiolipin of Bacillus stearothermophilus. Journal of Bacteriology 114, 1125-1137.

Cawthorne, M. A., Jeffries, L. R., Harris, M., Price, S. A., Diplock, A. T. \& GReEN, J. (1967). Menaquinone-4 and -5 in a bacterium. Biochemical Journal 104, 35C-36C.

Collns, M. D. (1981). Distribution of menaquinones within members of the genus Staphylococcus. FEMS Microbiology Letters 12, 83-85.

Collins, M. D. \& JoNES, D. (1981). Distribution of isoprenoid quinone structural types in bacteria and their taxonomic implications. Microbiological Reviews 45, 316-354.

Collins, M. D., Shah, H. N. \& Minnixin, D. E. (1980). A note on the separation of natural mixtures of bacterial menaquinones using reverse phase thinlayer chromatography. Journal of Applied Bacteriology 48, 277-282.

Collins, M. D., Goodfellow, M. \& Minnikin, D. E. $(1982 a)$. Fatty acid composition of some mycolic acid-containing coryneform bacteria. Journal of General Microbiology 128, 2503-2509.

Collins, M. D., Goodfellow, M. \& Minnikin, D. E. $(1982 b)$. Polar lipid composition in the classification of Arthrobacter and Microbacterium. FEMS Microbiology Letters 15, 299-302.

CONSDEN, R. \& GoRdON, A. H. (1948). Effect of salt on partition chromatograms. Nature, London 162, 180 181.

De Siervo, A. J. \& Salton, M. R. J. (1971). Biosynthesis of cardiolipin in the membranes of Micrococcus lysodeikticus. Biochimica et biophysica acta 239, 280-292.

DeVriese, L. A., HáJek, V., Oeding, P., Meyer, S. A. \& SCHLEIFER, K. H. (1978). Staphylococcus hyicus (Sompolinsky 1953) comb. nov. and Staphylococcus hyicus subsp. chromogenes subsp. nov. International Journal of Systematic Bacteriology 28, 482-490.

DitTMER, J. C. \& LesTeR, R. L. (1964). A simple specific spray for the detection of phospholipids on thin-layer chromatography. Journal of Lipid Research 5, 126-127.

Durham, D. R. \& KLoos, W. E. (1978). Comparative study of the total cellular fatty acids of Staphylococcus species of human origin. International Journal of Systematic Bacteriology 28, 223-228.

Feltham, R. K. A. (1979). A taxonomic study of the Micrococcaceae. Journal of Applied Bacteriology 47, 243-254.
Feltham, R. K. A. \& Sneath, P. H. A. (1982). Construction of matrices for computer-assisted identification of aerobic Gram-positive cocci. Journal of General Microbiology 128, 713-720.

Fischer, W., Narano, M., Laine, R. A. \& Bohrer, W. (1978). On the relationship between glycerolphosphoglycolipids and lipoteichoic acids in Gram-positive bacteria. I. The occurrence of phosphoglycolipids. Biochimica et biophysica acta 528, 288-297.

Frerman, F. E. \& White, D. C. (1967). Membrane lipid changes during formation of a functional electron transport system in Staphylococcus aureus. Journal of Bacteriology 94, 1868-1874.

GoOdfellow, M., Mordarsxi, M., Tkacz, A., SzYBA, K. \& Pulverer, G. (1980). Polynucleotide sequence divergence among some coagulase-negative staphylococci. Zentralblatt für Bakteriologie, Parasitenkunde, Infectionskrankheiten und Hygiene (Abteilung I, Originale A) 246, 10-22.

Goodfellow, M., Alderson, G., Nahaie, M. R., Peters, G., Schumacher-Perdreau, F., PUl verer, G., HeczKo, P. B. \& Mordarski, M. (1983). Numerical taxonomy of some staphylococci. Zentralblatt für Bakteriologie, Parasitenkunde, Infektionskrankheiten und Hygiene (Series A) 256, 7-24.

GouLD, R. M. \& LENNARZ, W. J. (1970). Metabolism of phosphatidylglycerol and lysyl phosphatidylglycerol in Staphylococcus aureus. Journal of Bacteriology 104, 1135-1144.

HÁSEK, V. (1976). Staphylococcus intermedius, a new species isolated from animals. International Journal of Systematic Bacteriology 26, 401-408.

HÁJEK, V. \& MARSALEK, E. (1971). The differentiation of pathogenic staphylococci and a suggestion for their taxonomic classification. Zentralblatt für Bakteriologie, Parasitenkunde, Infektionskrankheiten und Hygiene (Abteilung I, Originale A) 217, 176-182.

HÁJEK, V. \& MARSALEK, E. (1976). Evaluation of classificatory criteria for staphylococci. Zentralblatt für Bakteriologie, Parasitenkunde, Infektionskrankheiten und Hygiene (Abteilung I, Supplement 5), 11-21.

HÁJEK, V. \& SCHINDLER, J. (1981). Cluster analysis of coagulase-positive staphylococci. Zentralblatt für Bakteriologie, Mikrobiologie und Hygiene (Abteilung I, Supplement 10), 27-35.

HAMMOND, R. K. \& WHITE, D. C. (1969). Separation of vitamin $K_{2}$ isoprenologues by reverse-phase thinlayer chromatography. Journal of Chromatography 45, 446-452.

Heddaeus, H., Heczko, P. B., Mordarski, M., Goodfellow, M. \& Pulverer, G. (1978). Classification of coagulase-negative staphylococci according to recently proposed taxonomic schemes. FEMS Microbiology Letters 3, 135-137.

Heddaeus, H., HeczKo, P. B., Mordarski, M., GoOdFellow, M. \& PUlverer, G. (1981). Relationships between some characters of coagulase-negative staphylococci and DNA:DNA sequence homology. Zentralblatt für Bakteriologie, Mikrobiologie und Hygiene (Abteilung I, Supplement 10), 23-26.

Houtsmuller, U. M. T. \& VAN DeEnen, L. L. M. (1965). On the amino acid esters of phosphatidyl glycerol from bacteria. Biochimica et biophysica acta 106, 564-576. 
JACIN, H. \& Mishixin, A. R. (1965). Separation of carbohydrates on borate impregnated silica gel $\mathbf{G}$ plates. Journal of Chromatography 18, 170-173.

JEFFRIES, L. (1969). Menaquinones in the classification of Micrococcaceae, with observations on the application of lysozyme and novobiocin sensitivity tests. International Journal of Systematic Bacteriology 19, 183-187.

Jeffries, L., Harris, M. \& Price, S. A. (1967a). Atypical menaquinone pattern in a strain of Staphylococcus aureus. Nature, London 216, 808-809.

Jeffries, L., Cawthorne, M. A., Harris, M., Diplock, A. T., Green, J. \& Price, S. A. (1967b). Distribution of menaquinones in aerobic Micrococcaceae. Nature, London 215, 257-259.

Jeffries, L., Cawthorne, M. A., Harris, M., Cook, B. \& DiploCK, A. T. (1969). Menaquinone determination in the taxonomy of Micrococcaceae. Journal of General Microbiology 54, 365-380.

JoYCE, G. H., HAMmoND, R. K. \& White, D. C. (1970). Changes in membrane lipid composition in exponentially growing Staphylococcus aureus during the shift from 37 to $25^{\circ} \mathrm{C}$. Journal of Bacteriology 104, 323-330.

KILPPER-B̈̈LZ, R. \& SCHLEIFER, K. H. (1981). Transfer of Peptococcus saccharolyticus Foubert and Douglas to the genus Staphylococcus: Staphylococcus saccharolyticus (Foubert and Douglas) comb. nov. Zentralblatt für Bakteriologie, Mikrobiologie und Hygiene (Abteilung I, Originale C2), 331-334.

KLoOs, W. E. (1980). Natural populations of the genus Staphylococcus. Annual Review of Microbiology 34; 559-592.

Kloos, W. E. \& Schleifer, K. H. (1975). Simplified scheme for routine identification of human Staphylococcus species. Journal of Clinical Microbiology 1, 8287.

Kloos, W. E. \& Schleifer, K. H. (1981). The genus Staphylococcus. In The Prokaryotes. A Handbook on Habitats, Isolation and Identification of Bacteria, pp. 1548-1569. Edited by M. P. Starr, H. Stolp, H. G. Trüper, A. Balows \& H. G. Schlegel. Berlin: Springer Verlag.

Kloos, W. E. \& Schleifer, K. H. (1983). Staphylococcus auricularis sp. nov.: an inhabitant of the human external ear. International Journal of System atic Bacteriology 33, 9-14.

KLOOS, W. E. \& WolfshoHL, J. S. (1982). Identification of Staphylococcus species with the AP1 STAPHIDENT system. Journal of Clinical Microbiology 16, 509-516.

Komaratat, P. \& Kates, M. (1975). The lipid composition of a halotolerant species of Staphylococcus epidermidis. Biochimica et biophysica acta 398 , $464-484$.

Komura, I., Yamada, K. \& Komagata, K. (1975). Taxonomic significance of phospholipid composition in aerobic Gram-positive cocci. Journal of General and Applied Microbiology 21, 97-107.

Kushwaha, S. C. \& Kates, M. (1976). Nonpolar lipids of a halotolerant species of Staphylococcus epidermidis. Canadian Journal of Biochemistry 54, 79-85.

Lechevalier, M. P. (1977). Lipids in bacterial taxonomy. Critical Reviews in Microbiology 5, 109 210.

LecheValier, M. P., De Bièvre, C. \& Lechevalier,
H. (1977). Chemotaxonomy of aerobic actinomycetes: phospholipid composition. Biochemical Systematics and Ecology 5, 249-260.

Macfarlane, M. (1962). Lipid components of Staphylococcus aureus and Salmonella typhimurium. Biochemical Journal 82, 40P-41P.

MARPLES, R. R. (1981). Taxonomic studies of staphylococci and micrococci. Zentralblatt für Bakteriologie, Mikrobiologie und Hygiene (Abteilung I, Supplement 10), 9-13.

MeYER, S. A. \& SCHLEIfER, K. H. (1978). Deoxyribonucleic acid reassociation in the classification of coagulase-positive staphylococci. Archives of Microbiology 117, 183-188.

MinNIKIN, D. E. \& Goodfellow, M. (1980). Lipid composition in the classification and identification of acid-fast bacteria. In Microbiological Classification and Identification, pp. 189-256. Edited by $M$. Goodfellow \& R. G. Board. London: Academic Press.

MinNIKIN, D. E. \& Goodfellow, M. (1981). Lipids in the classification of Bacillus and related taxa. In The Aerobic Endospore-Forming Bacteria, pp. 59-103. Edited by R. C. W. Berkeley \& M. Goodfellow. London: Academic Press.

Minnikin, D. E., Goodfellow, M. \& Collins, M. D. (1978). Lipid composition in the classification and identification of coryneform and related taxa. In Coryneform Bacteria, pp. 85-160. Edited by I. J. Bousfield \& A. G. Callely. London: Academic Press.

Minnikin, D. E., Collins, M. D. \& Goodfellow, M. (1979). Fatty acid and polar lipid composition in the classification of Cellulomonas, Oerskovia and related taxa. Journal of Applied Bacteriology 47, 87-95.

Minnixin, D. E., O'DonNell, A. G., Goodfellow, M., Alderson, G., Athalye, M., Schanl, A. \& Parlett, J. H. (1984). An integrated procedure for the extraction of bacterial isoprenoid quinones and polar lipids. Journal of Microbiological Methods 2, 233-241.

Mordarski, M., Tkacz, A., Goodfellow, M., Pulverer, G., Peters, G. \& Schumacher-Perdreau, F. $(1981 a)$. Ribosomal ribonucleic acid similarities in the classification of Staphylococcus. FEMS Microbiology Letters 11, 159-163.

Mordarski, M., Goodfellow, M., Hecko, P. B., Peters, G., Pulverer, G., Tkacz, A. \& Kaszen, I. $(1981 b)$. Deoxyribonucleic acid pairing in the classification of the genus Staphylococcus. Zentralblatt für Bakteriologie, Mikrobiologie und Hygiene (Abteilung 1, Supplement 10), 15-21.

RÉdAI, I., RÉthy, A., SEbessi-GönCZY, P. \& VÁCZI, L. (1971). Lipids in Staphylococcus aureus and Escherichia coli cultured in the presence of human serum. Acta microbiologica Academiae scientiarum hungaricae 18, 297-306.

SCHLEIFER, K. H. \& FISCHER, U. (1982). Description of a new species of the genus Staphylococcus: Staphylococcus carnosus. International Journal of Systematic Bacteriology 32, 153-156.

Schleifer, K. H. \& Kandler, O. (1972). Peptidoglycan types of bacterial cell walls and their taxonomic implications. Bacteriological Reviews 36, 407-477.

SChleifer, K. H., Schumacher-PerdreaU, F., GötZ, F., Popp, B. \& HÁJex, V. (1976). Chemical and biochemical studies for the differentiation of coagu- 
lase-positive staphylococci. Archives of Microbiology 110, 263-270.

SChleifer, K. H., Meyer, S. A. \& Rupprecht, M. (1979). Relatedness among coagulase-negative staphylococci: deoxyribonucleic acid reassociation and comparative immunological studies. Archives of Microbiology 122, 93-101.

SCHLEIFER, K. H., KILPPER-Bälz, R., FischeR, V., FALLER, A. \& ENDL, J. (1982). Identification of 'Micrococcus candidus' ATCC 14852 as a strain of Staphylococcus epidermidis and of 'Micrococcus caseolyticus' ATCC 13548 and Micrococcus varians ATCC 29750 as members of a new species, Staphylococcus caseolyticus. International Journal of Systematic Bacteriology 32, 15-20.

Schumacher-Perdreau, F., Rotering, H. \& PulVERER, G. (1983). Cell wall analysis and taxonomy of staphylococci. Zentralblatt für Bakteriologie, Parasitenkunde, Infektionskrankheiten und Hygiene (Series A) 256, 25-36.

SHAw, N. (1968). The detection of lipids on thin-layer chromatograms with the periodate-Schiff reagent. Biochimica et biophysica acta 164, 435-436.

SHaw, N. (1975). Bacterial glycolipids and glycophospholipids. Advances in Microbial Physiology 12, 141-167.

ShORT, S. A. \& WhITE, D. C. (1970). Metabolism of the glucosyl diglycerides and phosphatidylglucose of Staphylococcus aureus. Journal of Bacteriology 104, 126-132.

Sincoweay, H., Miyagawa, E. \& Kume, T. (1981). Cellular fatty acid composition in staphylococci isolated from bovine milk. National Institute of Animal Health Quarterly (Japan) 21, 14-20.
Skerman, V. B. D., McGowan, V. \& Sneath, P. H. A. (1980). Approved lists of bacterial names. International Journal of Systematic Bacteriology 30, 225420.

StaCkebrandt, E. \& Woese, C. R. (1979). A phylogenetic dissection of the family Micrococcaceae. Current Microbiology 2, 317-322.

StackebrandT, E. \& WoEsE, C. R. (1981). The evolution of prokaryotes. In Molecular and Cellular Aspects of Microbial Evolution, pp. 1-31. Edited by M. J. Carlile, J. F. Collins \& B. E. B. Moseley. Cambridge: Cambridge University Press.

WeCKBaCh, L. S. \& LANGLoIS, B. E. (1976). Classification by numerical taxonomy of staphylococci isolated from the bovine udder. Journal of Milk Food Technology 39, 246-249.

Wellington, E. M. H. \& Williams, S. T. (1979). Preservation of actinomycete inoculum in frozen glycerol. Microbios Letters 6, 151-157.

White, D. C. \& Frerman, F. E. (1967). Extraction, characterization and cellular localization of the lipids of Staphylococcus aureus. Journal of Bacteriology 94, 1854-1867.

Whiteside, T. L., De Siervo, A. \& Salton, M. R. J. (1971). Use of antibody to membrane adenosine triphosphatase in the study of bacterial relationships. Journal of Bacteriology 105, 957-967.

Yamada, Y., InOUYe, G., TaHaRA, Y. \& Kondo, K. (1976). The menaquinone system in the classification of aerobic Gram-positive cocci in the genera Micrococcus, Staphylococcus, Planococcus, and Sporosarcina. Journal of General and Applied Microbiology 22, 227-236. 